\title{
Improved model of isoprene emissions in Africa using Ozone Monitoring Instrument (OMI) satellite observations of formaldehyde: implications for oxidants and particulate matter
}

\author{
E. A. Marais ${ }^{1, *}$, D. J. Jacob ${ }^{1,2}$, A. Guenther ${ }^{3}$, K. Chance ${ }^{4}$, T. P. Kurosu ${ }^{5}$, J. G. Murphy ${ }^{6}$, C. E. Reeves ${ }^{7}$, and \\ H. O. T. Pye ${ }^{8}$ \\ ${ }^{1}$ Earth and Planetary Sciences, Harvard University, Cambridge, MA, USA \\ ${ }^{2}$ School of Engineering and Applied Sciences, Harvard University, Cambridge, MA, USA \\ ${ }^{3}$ Pacific Northwest National Laboratory, Richland, WA, USA \\ ${ }^{4}$ Harvard-Smithsonian Center for Astrophysics, Cambridge, MA, USA \\ ${ }^{5}$ Earth Atmosphere Science, Jet Propulsion Laboratory, Pasadena, CA, USA \\ ${ }^{6}$ Department of Chemistry, University of Toronto, Toronto, Canada \\ ${ }^{7}$ School of Environmental Sciences, University of East Anglia, Norwich, UK \\ ${ }^{8}$ National Exposure Research Laboratory, US EPA, Research Triangle Park, NC, USA \\ *now at: School of Engineering and Applied Sciences, Harvard University, Cambridge, MA, USA
}

Correspondence to: E. A. Marais (emarais@ seas.harvard.edu)

Received: 3 February 2014 - Published in Atmos. Chem. Phys. Discuss.: 14 March 2014

Revised: 27 May 2014 - Accepted: 20 June 2014 - Published: 1 August 2014

\begin{abstract}
We use a 2005-2009 record of isoprene emissions over Africa derived from Ozone Monitoring Instrument (OMI) satellite observations of formaldehyde (HCHO) to better understand the factors controlling isoprene emission in the continent and evaluate the impact on atmospheric composition. OMI-derived isoprene emissions show large seasonality over savannas driven by temperature and leaf area index (LAI), and much weaker seasonality over equatorial forests driven by temperature. The commonly used MEGAN (Model of Emissions of Gases and Aerosols from Nature, version 2.1) global isoprene emission model reproduces this seasonality but is biased high, particularly for equatorial forests, when compared to OMI and relaxed-eddy accumulation measurements. Isoprene emissions in MEGAN are computed as the product of an emission factor $E_{o}$, LAI, and activity factors dependent on environmental variables. We use the OMI-derived emissions to provide improved estimates of $E_{o}$ that are in good agreement with direct leaf measurements from field campaigns $(r=0.55$, bias $=-19 \%)$. The largest downward corrections to MEGAN $E_{o}$ values are for equatorial forests and semi-arid environments, and this is consistent with latitudinal transects of isoprene over
\end{abstract}

western Africa from the African Monsoon Multidisciplinary Analysis (AMMA) aircraft campaign. Total emission of isoprene in Africa is estimated to be $77 \mathrm{Tg} \mathrm{Ca}^{-1}$, compared to $104 \mathrm{Tg} \mathrm{Ca}^{-1}$ in MEGAN. Simulations with the GEOSChem oxidant-aerosol model suggest that isoprene emissions increase mean surface ozone in western Africa by up to $8 \mathrm{ppbv}$, and particulate matter by up to $1.5 \mu \mathrm{g} \mathrm{m}^{-3}$, due to coupling with anthropogenic influences.

\section{Introduction}

Isoprene is the dominant biogenic non-methane volatile organic compound (NMVOC) emitted by vegetation, accounting for about $50 \%$ of global NMVOC emissions in current inventories (Olivier et al,. 1996; Guenther et al., 2006). Isoprene affects the oxidative capacity of the atmosphere through reaction with $\mathrm{OH}$ (Ren et al., 2008; Lelieveld et al., 2008) and as a precursor of $\mathrm{O}_{3}$ (Trainer et al., 1987). It is also an important precursor for secondary organic aerosols (SOAs) (Claeys et al., 2004) and a temporary reservoir for nitrogen oxide radicals $\left(\mathrm{NO}_{\mathrm{x}} \equiv \mathrm{NO}+\mathrm{NO}_{2}\right)$ by formation 
of organic nitrates (Paulot et al., 2012). Isoprene thus has a range of impacts on air quality and climate that need to be included in atmospheric composition models. The widely used global Model of Emissions of Gases and Aerosols from Nature (MEGAN; Guenther et al., 2006, 2012) indicates that $80 \%$ of global isoprene emission takes place in the tropics and $25 \%$ in Africa, but there are large uncertainties in these estimates due to lack of data. In previous work we developed a method to estimate isoprene emissions from Africa on the basis of observations of formaldehyde (HCHO) from the Ozone Monitoring Instrument (OMI) satellite instrument (Marais et al., 2012). Here we use our OMI-derived isoprene emissions evaluated with local data to better understand the factors controlling isoprene emissions in Africa, improve emission estimates for different African plant functional types (PFTs), and assess the implications for atmospheric oxidants and aerosols.

Isoprene produced in the chloroplasts of plants is released to the atmosphere via the stomata of leaves (Sharkey and Yeh, 2001). Above-canopy emission fluxes $E_{\mathrm{ISOP}}$ depend on plant species, foliage density, leaf age, temperature, photosynthetically active radiation (PAR), and water stress (Guenther et al., 1995). This is commonly represented in isoprene emission models by multiplying an emission factor $E_{o}$ defined for each PFT at standard conditions with an ensemble of coefficients describing the sensitivity to local environmental variables. In the MEGAN (version 2.1) inventory (Guenther et al., 2012) this is given as

$E_{\mathrm{ISOP}}=E_{o} \times C_{\mathrm{CE}} \times \mathrm{LAI} \times \gamma_{\mathrm{PAR}} \times \gamma_{T} \times \gamma_{\mathrm{AGE}} \times \gamma_{\mathrm{SM}}$,

where LAI is the leaf area index $\left(\mathrm{m}^{2}\right.$ leaf surface per $\mathrm{m}^{2}$ of Earth surface) and the dimensionless activity factors $\gamma$ describe the sensitivity to above-canopy radiation (PAR), air temperature $(T)$, leaf age distribution (AGE), and soil moisture (SM). The coefficient $C_{\mathrm{CE}}=1.3\left(\mathrm{~m}^{2}\right.$ Earth surface per $\mathrm{m}^{2}$ leaf surface) enforces $E_{\mathrm{ISOP}}=E_{o}$ under standard conditions, which for MEGAN are defined as $T=$ $303 \mathrm{~K}$; PAR $=1000 \mu \mathrm{mol}$ photons $\mathrm{m}^{-2} \mathrm{~s}^{-1}$; a canopy with $\mathrm{LAI}=5 \mathrm{~m}^{2} \mathrm{~m}^{-2}$; leaf age distribution of $80 \%$ mature, $10 \%$ growing, and $10 \%$ senescing leaves; and volumetric soil moisture of $0.3 \mathrm{~m}^{3} \mathrm{~m}^{-3}$.

Isoprene emission data for African vegetation are very limited, and emission models require extrapolation of data from other continents and across plant species (Guenther et al., 2006, 2012). This can lead to substantial errors, as differences in isoprene fluxes within and across plant species are large. Uncertainty in the distribution of land cover (PFT) adds to the uncertainty (Pfister et al., 2008).

Space-based observations of HCHO, a high-yield oxidation product of isoprene, have been used in a number of studies to infer isoprene emissions and evaluate inventories globally (Shim et al., 2005; Stavrakou et al., 2009a, b) and regionally in southeastern Asia (Fu et al., 2007), South America (Barkley et al., 2008), North America (Palmer et al.,
2003, 2006; Millet et al., 2008), Europe (Dufour et al., 2009; Curci et al., 2010), and Africa (Marais et al., 2012). These studies have confirmed temperature as the dominant factor controlling month-to-month variability of isoprene emissions across North America (Palmer et al., 2006; Millet et al., 2008) and Amazonia (Barkley et al., 2008). Leaf phenology and PAR were found to be additional important drivers of isoprene emission seasonality in Amazonia (Barkley et al., 2008, 2009). Stavrakou et al. (2009a) found that water stress reduces isoprene emissions in southern Africa during the dry season. Here we use our previous work for Africa (Marais et al., 2012) to better understand the factors controlling isoprene emissions across the African continent and evaluate and improve the MEGANv2.1 emission inventory.

\section{OMI-derived isoprene emissions in Africa}

The derivation of isoprene emissions in Africa using OMI HCHO data is described in Marais et al. (2012) and summarized briefly here. OMI is a UV/VIS solar backscatter instrument on the Aura polar Sun-synchronous satellite launched in 2004 (Levelt et al., 2006). It has a $13 \mathrm{~km} \times 24 \mathrm{~km}$ nadir pixel resolution, daily global coverage through crosstrack viewing, and 13:30 local time (LT) overpass. HCHO slant columns are obtained from Version 2.0 (Collection 3) retrievals for 2005-2009 (http://disc.sci.gsfc.nasa.gov/Aura/ data-holdings/OMI/omhcho_v003.shtml). They are corrected for instrument drift and converted to vertical columns using local air mass factors (AMFs) for the scattering atmosphere (Palmer et al., 2001) with vertical HCHO profiles from the GEOS-Chem chemical transport model (CTM) v901-03 (http://www.geos-chem.org) and scattering weights from the LIDORT (linearized discrete ordinate) radiative transfer model (Spurr et al., 2001).

$\mathrm{HCHO}$ enhancements over Africa primarily originate from isoprene emission, biomass burning, and fuel combustion. Scenes affected by biomass burning are excluded on the basis of MODIS (Moderate Resolution Imaging Spectroradiometer) satellite observations of fire counts and OMI satellite observations of aerosol absorption optical depth (AAOD) (Torres et al., 2007). Scenes affected by gas flaring are excluded on the basis of a specialized hotspot product from the Advanced Along Track Scanning Radiometer (AATSR) satellite sensor (Casadio et al., 2012), and this leads to the exclusion of much of Nigeria where that source is particularly large and urban and industrial sources may contribute as well (Marais et al., 2014).

Marais et al. (2012) thus obtained a 2005-2009 monthly data set of vertical $\mathrm{HCHO}$ columns with $1^{\circ} \times 1^{\circ}$ spatial resolution screened against biomass burning and anthropogenic influences and thus attributable to isoprene emissions (Fig. 1, left panel). They used GEOS-Chem to derive the sensitivity, $S$, of the $\mathrm{HCHO}$ column $\left(\Omega_{\mathrm{HCHO}}\right)$ at 12:00-15:00 LT to a perturbation $\Delta$ in isoprene emission 

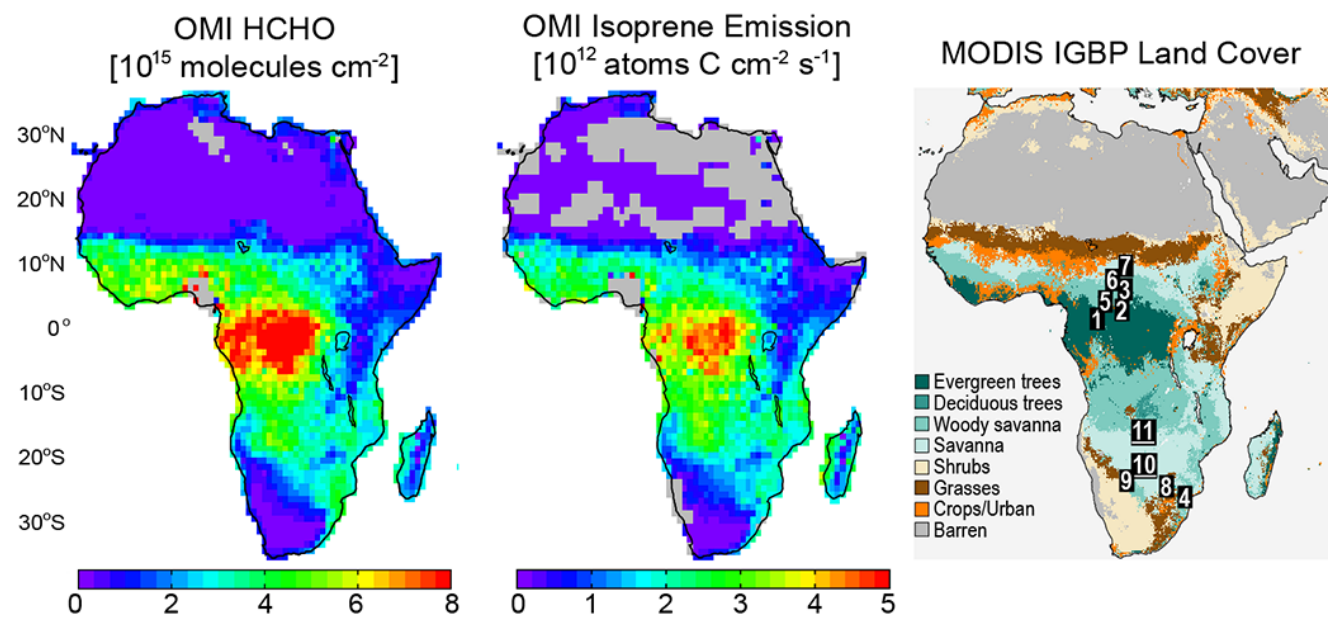

Figure 1. Annual mean (2005-2009) OMI HCHO vertical columns at $1^{\circ} \times 1^{\circ}$ horizontal resolution screened against biomass burning and anthropogenic HCHO (left), and resulting OMI-derived isoprene emissions (center), as derived by Marais et al. (2012) and summarized in the text. The OMI observations are at 13:30 local time (LT) and the OMI-derived isoprene emissions are for 12:00-15:00 LT. The right panel is a MODIS IGBP land cover map (Friedl et al., 2002) with numbers showing the location of isoprene flux measurements used to evaluate the OMI-derived isoprene emissions (Table 1a and b).

$\left(S=\Delta \Omega_{\mathrm{HCHO}} / \Delta E_{\mathrm{ISOP}}\right)$. Values of $S$ increase linearly with $\mathrm{NO}_{\mathrm{x}}$ under low- $\mathrm{NO}_{\mathrm{x}}$ conditions (boundary-layer $\mathrm{NO}_{\mathrm{x}}<$ 500 pptv) and remain constant above 500 pptv $\mathrm{NO}_{\mathrm{x}}$. The local regime for individual scenes was determined from concurrent observations of OMI tropospheric $\mathrm{NO}_{2}$ columns. Scenes affected by smearing (displacement of $\mathrm{HCHO}$ from the isoprene emission source) were diagnosed with anomalously high values of $S$ and excluded from the data set. See Marais et al. (2012) for further details.

Marais et al. (2012) obtained in this manner a monthly isoprene emission inventory for 2005-2009 on a $1^{\circ} \times 1^{\circ}$ grid (Fig. 1, center panel). The OMI overpass is at 13:30 LT and the corresponding isoprene emissions are for 12:0015:00 LT, typically the diurnal maximum. Also shown in Fig. 1 is the MODIS IGBP (International Geosphere Biosphere Programme) land cover map (Friedl et al., 2002). Dominant vegetation types in Africa are roughly defined by latitudinal bands, with evergreen (broadleaf) trees along the Equator successively transitioning to the north and south to woody savannas (30-60\% tree coverage), savannas (10$30 \%$ ), grasslands, and deserts. The HCHO column data follow this vegetation gradient and so do the inferred isoprene emissions.

Marais et al. (2012) presented a detailed error characterization of their OMI-derived isoprene emissions. Spectral fitting of the HCHO column has an error standard deviation of $8 \times 10^{15}$ molecules $\mathrm{cm}^{-2}$ for individual observations. Relating the fitted slant $\mathrm{HCHO}$ columns to isoprene emissions incurs errors in the AMF estimate (20\%), the isoprene oxidation mechanism (15\%), the use of $\mathrm{OMI} \mathrm{NO}_{2}$ to obtain $S$ under low- $\mathrm{NO}_{\mathrm{x}}$ conditions $(20-40 \%)$, and smearing (30\% for high- $\mathrm{NO}_{\mathrm{x}}$ conditions, $30-70 \%$ for low- $\mathrm{NO}_{\mathrm{x}}$ ).
The resulting error in isoprene emission estimates for individual scenes, adding in quadrature all error contributions, is $40 \%$ for high- $\mathrm{NO}_{\mathrm{x}}$ conditions and $40-90 \%$ for low- $\mathrm{NO}_{\mathrm{x}}$ conditions (Marais et al., 2012). A monthly mean estimate for a $1^{\circ} \times 1^{\circ}$ grid square typically averages 3000 individual scenes. Averaging reduces the error though only to the extent that the error components are random.

\section{Evaluation with canopy flux measurements}

Canopy-scale isoprene flux measurements by relaxed-eddy accumulation (REA) are available from a few African field campaigns (Table 1a). Figure 2 compares OMI-derived isoprene emissions to REA measurements over equatorial evergreen trees (Greenberg et al., 1999; Serça et al., 2001), woody savannas (Greenberg et al., 1999), and savannas (Harley et al., 2003) in central and southern Africa (sites 1-4 in Fig. 1 and Table 1a). Also shown are the values calculated using Eq. (1) with MEGANv2.1 emission factors, combined Terra and Aqua MODIS LAI (Yang et al., 2006), and the Goddard Earth Observing System (GEOS-5) assimilated meteorological data. The Serça et al. (2001) and Harley et al. (2003) measurements (sites 1 and 4) are from walk-up towers with a flux footprint of about $600 \mathrm{~m}$, while the Greenberg et al. (1999) measurements (sites 2 and 3) are from aircraft with a flux footprint of $\sim 100 \mathrm{~km} \times 100 \mathrm{~km}$ at site 2 and $30 \mathrm{~km} \times 30 \mathrm{~km}$ at site 3 . All values in Fig. 2 are for 12:00 15:00 LT. REA fluxes at sites 2-3, obtained in the morning (9:30-11:30), are increased by a factor of 1.4 as a diurnal correction for temperature and PAR following MEGAN. 
Table 1a. Relaxed-eddy accumulation (REA) isoprene flux measurements in Africa ${ }^{\mathrm{a}}$.

\begin{tabular}{|c|c|c|c|c|c|c|}
\hline \multirow{2}{*}{ Site $^{\mathrm{b}}$} & \multicolumn{2}{|c|}{ Observation period } & \multirow{2}{*}{ Platform } & \multirow{2}{*}{$\begin{array}{c}E_{\mathrm{ISOP}} \\
{\left[10^{12} \text { atoms } \mathrm{C} \mathrm{cm}^{-2} \mathrm{~s}^{-1}\right]^{\mathrm{c}}}\end{array}$} & \multirow{2}{*}{ Land cover ${ }^{d}$} & \multirow{2}{*}{ Reference } \\
\hline & Date & Time & & & & \\
\hline \multirow[t]{2}{*}{1} & Mar 1996 & 12:00-13:00 LT & Tower & 3.5 & Equatorial trees & Serça et al. (2001) \\
\hline & Nov 1996 & 12:00-13:00 LT & & 1.4 & & \\
\hline 2 & Nov-Dec 1996 & 09:30-11:30 LT & Aircraft & 1.5 & Equatorial trees & Greenberg et al. (1999) \\
\hline 3 & Nov-Dec 1996 & 09:30-11:30 LT & Aircraft & 0.91 & Woody savanna & Greenberg et al. (1999) \\
\hline 4 & Feb 2001 & 12:00-13:00 LT & Tower & 1.2 & Savanna & Harley et al. (2003) \\
\hline
\end{tabular}

${ }^{a}$ Data used to evaluate OMI-derived and MEGAN isoprene emissions (Fig. 2). ${ }^{\text {b }}$ See Fig. 1 for the location of each site. ${ }^{\mathrm{c}}$ Mean values at 12:00-15:00 local time. ${ }^{\mathrm{d}}$ MODIS IGBP land cover classification (Fig. 1).

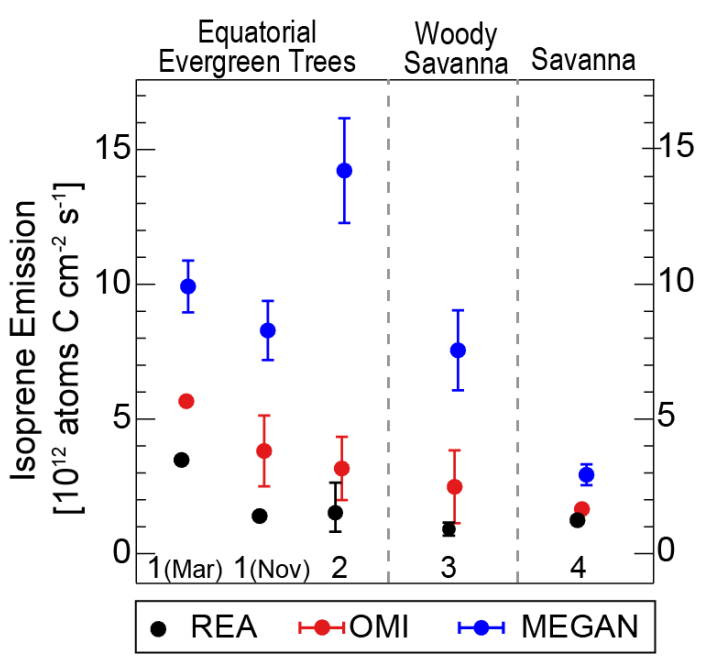

Figure 2. Mean canopy-scale isoprene emissions at African sites 14 (see Fig. 1 and Table 1a) measured by relaxed-eddy accumulation (REA), and comparison to OMI-derived and MEGAN values. All values are for 12:00-15:00 local time, with diurnal correction for REA measurements at sites 2 and 3 (see text). Vertical bars on the REA measurements for sites 2-3 are the interquartile ranges over the aircraft sampling domain given in Greenberg et al. (1999). OMIderived and MEGAN values are 2005-2009 monthly averages for the site locations and observation times, with interannual standard deviations shown as vertical bars. Mar: March; Nov: November.

No correction is applied to the REA flux measurements to account for interannual variability between 1996 (sites 13), 2001 (site 4), and the satellite observation period (20052009). As will be discussed in Sect. 4, temperature is the dominant modulator of isoprene emissions in Africa, and it does not drive significant interannual variability except in northern savannas in August (not represented in Fig. 2).

OMI and MEGAN are sampled for the $1^{\circ} \times 1^{\circ}$ grid square coincident with the observation site and for the corresponding months. Interannual variability is of similar magnitude in the OMI-derived and MEGAN data at sites 1 (November), 2 , and 3 where multi-year OMI data are available. The variability is driven in MEGAN predominantly by temperature.
At site 3 there are no OMI data in the months of observation (November-December) because of biomass burning interference, and we show instead OMI-derived emissions in September-October, which should be similar to NovemberDecember at this site according to MEGAN.

For the equatorial evergreen tree sites in central Africa (sites 1 and 2) OMI-derived isoprene emissions are on average 2 times higher than the REA measurements, and MEGAN is 5 times higher. The flux tower sampled vegetation with a relatively low fraction of isoprene emitters. Nearby landscapes include monodominant stands of the Gilbertiodendron trees that have a high isoprene emission factor (Serça et al., 2001). The distribution of this tree species beyond the sampling domain is uncertain and application of its emission factor to land cover in equatorial Africa contributes to the overestimate in MEGAN. OMI and MEGAN reproduce the March-November decline at site 1, and this is driven in MEGAN by temperature.

Fluxes at site 2, where the REA sampling footprint is similar to OMI, have large spatial variability, implying that differences in the sampling footprint contribute to discrepancies at other sites. Greenberg et al. (1999) applied a positive correction of $\sim 20 \%$ to flux measurements at sites 2-3 to account for the transport of isoprene that was not accumulated in the two REA reservoirs. A similar negative bias may affect measurements at sites 1 and 4, but the reported values have not been adjusted. The aircraft REA measurements (sites 2 and 3) may have an additional negative bias of $\sim 25 \%$ due to the vertical flux divergence between the measurement altitude and the surface (Karl et al., 2013).

At the woody savanna site OMI is 2.2 times higher than the REA measurement (1.8 times higher if a $25 \%$ upward correction is applied to the REA measurement), while MEGAN is 8 times higher. At the savanna site $\mathrm{OMI}$ is 1.3 times higher than the REA flux measurement, while MEGAN is 2.4 times higher. The discrepancy at site 4 is partly due to the low $(<10 \%)$ proportion of isoprene-emitting vegetation within the flux tower footprint as compared to $\sim 35 \%$ for savannas surveyed at surrounding field sites (Harley et al., 2003). 


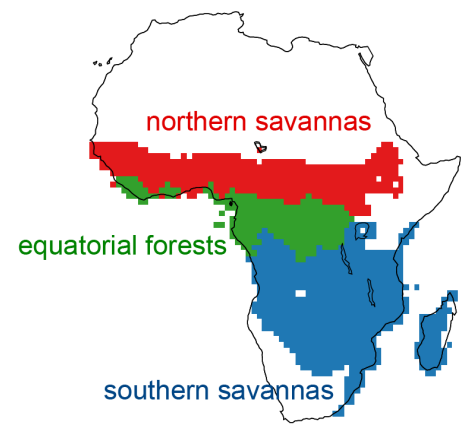

Figure 3. Coherent regions used for analysis of the factors controlling OMI-derived isoprene emissions. Land cover definitions are from the MODIS IGBP map (Fig. 1).

Overall the REA flux measurements indicate canopy-scale isoprene emissions that are somewhat lower than derived from OMI and much lower than derived from MEGAN. As we will show in Sect. 5, landscape-level isoprene emission factors measured during African field campaigns are more consistent with OMI.

\section{Seasonality of isoprene emissions in Africa}

We examined the factors driving the seasonality of OMIderived isoprene emissions, focusing on three seasonally and ecologically coherent regions in Africa where emissions are highest (Fig. 3): (1) equatorial forests dominated by tropical broadleaf evergreen trees, (2) northern savannas (including woody), and (3) southern savannas (including woody). Figure 4 shows the seasonality of OMI-derived isoprene emissions for these three regions together with MODIS LAI and GEOS-5 $2 \mathrm{~m}$ air temperature. Isoprene emissions and $2 \mathrm{~m}$ temperature are for 12:00-15:00 LT, and MODIS LAI is the combined Terra and Aqua product (Yang et al., 2006). Multiyear averages (2005-2009) are shown; the regionally averaged interannual variability is small, except over northern savannas in August as discussed below. Soil moisture and PAR are not included in Fig. 4 as soil moisture only appears to affect southern savannas during the dry season, and PAR in southern and northern savannas is convolved with temperature.

OMI-derived isoprene emissions for equatorial forests are a factor of 2 lower than MEGAN, and both show similar weak seasonality, with a decline from March to November that is consistent with Serça et al. (2001) (Fig. 2) and is driven in MEGAN principally by temperature. Although LAI exhibits similar seasonality, it remains above $3.5 \mathrm{~m}^{2} \mathrm{~m}^{-2}$ yearround, and MEGAN is not sensitive to LAI values above 2$3 \mathrm{~m}^{2} \mathrm{~m}^{-2}$ due to shading of lower-canopy leaves (Guenther et al., 2006).
Availability of OMI-derived isoprene emission data for the northern savannas is limited to April-November because of pervasive biomass burning influence during the DecemberMarch dry season. Emissions are maximum in April, at the beginning of the wet season, and minimum in August when the West African monsoon (WAM) is fully developed over the continent (Janicot et al., 2008), resulting in cooler temperatures. OMI-derived emissions largely follow temperature over the April-November period. Year-to-year variability in the WAM affects temperature in August, leading to interannual variability in August OMI isoprene emissions over the 2005-2009 period that is correlated with temperature $(r=0.55)$.

The complete seasonality simulated by MEGAN in northern savannas shows low isoprene emissions in the December-March dry season when LAI is less than $1 \mathrm{~m}^{2} \mathrm{~m}^{-2}$, and a broad maximum in the April-November wet season as the August minimum in temperature is compensated by a corresponding maximum in LAI. MODIS LAI in the northern savannas is less than $2.5 \mathrm{~m}^{2} \mathrm{~m}^{-2}$ year-round, sufficiently low that the MEGAN dependence on LAI does not saturate (Guenther et al., 2012). However, MODIS may underestimate LAI in western Africa during the wet season because of cloud contamination (Gessner et al., 2013).

OMI-derived emissions for southern savannas are in close agreement with MEGAN, featuring a minimum in the winter dry season and a maximum in the summer wet season. The seasonal minimum follows that of temperature (June-July) with a 1-month lag that reflects the very dry conditions in July-September. We find that LAI and temperature are both important for driving the seasonality of isoprene emissions in southern savannas.

\section{Satellite-derived isoprene emission factors for Africa}

The general ability of MEGAN to reproduce the seasonal variation of OMI-derived isoprene emissions suggests that the MEGAN activity factors ( $\gamma$ in Eq. 1 ) are appropriate for conditions in Africa, with temperature and LAI as the principal drivers. The large MEGAN bias over equatorial forests and northern savannas can therefore be attributed to an overestimate of emission factors ( $E_{o}$ in Eq. 1$)$.

The emission factors in MEGAN represent isoprene fluxes for a canopy with leaves at standard conditions of air temperature $(T=303 \mathrm{~K})$ and light $\left(\mathrm{PAR}=1000 \mu \mathrm{mol}\right.$ photons $\left.\mathrm{m}^{-2} \mathrm{~s}^{-1}\right)$. They are gridded using a detailed regional land cover map for Africa south of the Equator (Otter et al., 2003) and the Olson et al. (2001) global ecoregion data in the north (Guenther et al., 2006). Here we infer emission factors $\left(E_{0}\right)$ from the OMI-derived canopy-level isoprene emission data ( $\left.E_{\text {ISOP }}\right)$ using Eq. (1). In so doing we only consider data with individual activity factors $\gamma$ in the range $0.5-1.5$ so as to avoid errors driven by large departures from standard conditions. 


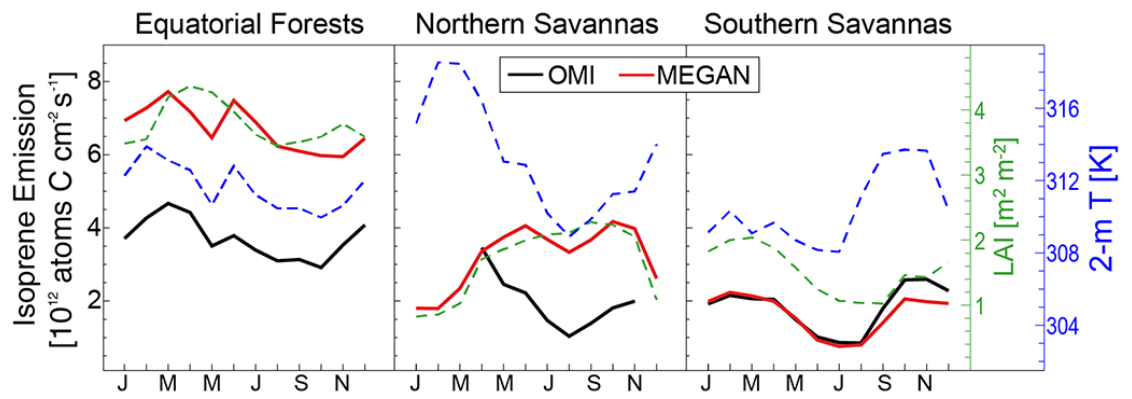

Figure 4. Seasonality of isoprene emissions and environmental variables averaged over the coherent African regions of Fig. 3. Monthly mean OMI-derived (black) and MEGAN (red) isoprene emissions are shown together with GEOS-5 2 m temperature (blue) and MODIS LAI (green). OMI-derived isoprene emissions are not available for northern savannas in December-March because of biomass burning interference. Emissions and $2 \mathrm{~m}$ temperature are for 12:00-15:00 LT. LAI is the combined Terra and Aqua product (Yang et al., 2006). All data are means for 2005-2009.

Table 1b. Leaf-level isoprene flux measurements in Africa ${ }^{\mathrm{a}}$.

\begin{tabular}{llcll}
\hline Site $^{\mathrm{b}}$ & Observation period & $\begin{array}{c}E_{o} \\
{\left[\mathrm{mg} \mathrm{C} \mathrm{m}^{-2} \mathrm{~h}^{-1}\right]}\end{array}$ & Land cover & Reference \\
\hline 1 & 1996 & 3.6 & Equatorial trees & Serça et al. (2001) \\
2 & $1995-1996$ & 1.0 & Equatorial trees & Klinger et al. (1998) \\
3 & $1995-1996$ & 1.2 & Woody savanna & Greenberg et al. (1999) \\
4 & Feb 2001 & 0.47 & Savanna & Harley et al. (2003) \\
& Dec 1992 & 2.4 & Savanna & Guenther et al. (1996) \\
5 & 1995-1996 & 1.4 & Woody savanna & Klinger et al. (1998) \\
6 & 1995-1996 & 3.0 & Woody savanna & Klinger et al. (1998) \\
7 & 1995-1996 & 0.95 & Savanna & Klinger et al. (1998) \\
8 & Dec 1992 & 4.4 & Savanna & Guenther et al. (1996) \\
& Feb-Mar 2001 & 4.5 & Savanna & Otter et al. (2002) \\
9 & Feb-Mar 2001 & 0.70 & Shrubs & Otter et al. (2002) \\
10 & Feb-Mar 2001 & 0.70 & Savanna & Otter et al. (2002) \\
11 & Feb-Mar 2001 & 8.2 & Woody savanna & Otter et al. (2002) \\
& Feb-Mar 2001 & 3.6 & Woody savanna & Otter et al. (2002) \\
\hline
\end{tabular}

a Emission factors $E_{O}$ for standard conditions of temperature and PAR (Eq. 1) used to compare to MEGAN and OMI-derived values in Fig. $5 .{ }^{\mathrm{b}}$ See Fig. 1 for the location of each site. ${ }^{\mathrm{c}}$ MODIS IGBP land cover classification (Fig. 1).

Figure 5 shows the resulting distributions of MEGAN and OMI emission factors $E_{o}$ over Africa together with observations from the field campaigns of Table $1 \mathrm{~b}$. The latter are at the landscape level and were obtained by scaling measured leaf-level isoprene fluxes for representative plant species with foliage density and species distribution data. Leaf-level measurements at standard conditions were obtained by using enclosure measurements with controlled temperature and PAR (Serça et al., 2001; Otter et al., 2002), or adjusting to standard conditions with MEGAN activity factors for temperature and PAR (Guenther et al., 1996). For the former an upward correction applied to the Serça et al. (2001) landscape emission factor accounts for isoprene fluxes obtained from shade-adapted leaves that have lower emissions at standard conditions than sunlit leaves (Guenther et al., 1999). Leaf-level fluxes of Klinger et al. (1998) were determined to be at standard conditions with coincident measurements of temperature and PAR, but we exclude the data from shaded leaves at dense forest sites.

We find from Fig. 5 remarkable agreement between OMIderived emission factors and the field data $(r=0.55$, OMI normalized mean bias $=-19 \%$ ). Woody savannas in Zambia and savannas in South Africa have large variability in $E_{o}\left(0.5-4.5 \mathrm{mg} \mathrm{C} \mathrm{m}^{-2} \mathrm{~h}^{-1}\right)$, which is reproduced by OMI. The two sites in Botswana have low emission factors as the site to the north is dominated by monoterpene-emitting mopane vegetation, while the site to the south is predominantly shrubland (Otter et al., 2002).

Differences between OMI and MEGAN emission factors are largest for equatorial forests, and the field enclosure observations are in good agreement with OMI and much lower than MEGAN. The equatorial forest enclosure measurements are used in MEGAN to estimate emission factors there, but a large positive correction is applied to account for leaf 


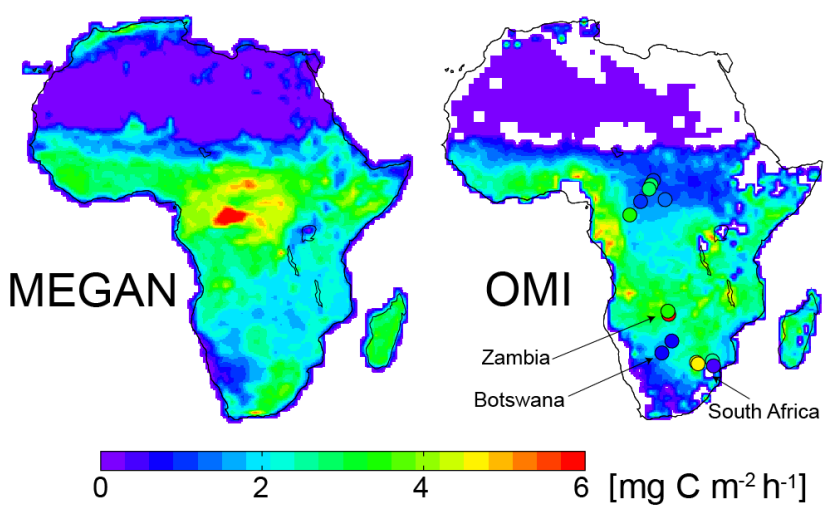

Figure 5. Isoprene emission factors ( $E_{O}$ in Eq. 1) representing the emission flux under standard conditions. Measured landscape-level emission factors from field sites (circles; see Fig. 1 and Table 1b) are compared to those used in MEGAN (left) and obtained with OMI (right). White indicates missing OMI data.

enclosure measurements of shade-adapted leaves. Our OMIderived emission factors do not support such a correction, and this is also reflected in the MEGAN overestimate of REA flux measurements (Fig. 2). OMI emission factors for equatorial forests are larger in the west than east, and this may result from differences in the proportion of isoprene-emitting species. The west is dominated by dry tropical forests, while the east is dominated by permanently or seasonally flooded forests (White, 1983).

Table 2 shows mean isoprene emission factors for individual PFTs as obtained by mapping the data from Fig. 5 onto the MODIS IGBP land map (Fig. 1; Friedl et al., 2002) and the Global Land Cover (GLC) 2000 land map (Mayaux et al., 2006). The distribution of MODIS IGBP woody savannas is spatially consistent with GLC 2000 broadleaf trees, and MODIS IGBP savannas correspond to GLC 2000 shrubs interspersed with broadleaf trees and cultivated land. The GLC 2000 classification scheme is more consistent with the PFTs of MEGANv2.1 (Guenther et al., 2012). OMI gives higher emission factors for forested vegetation than for grasslands, but the difference is not as large as MEGAN and more consistent with the field enclosure observations. The largest differences between OMI and MEGAN emission factors are for broadleaf evergreen trees and for semi-arid vegetation (shrubs and herbs).

The OMI-derived emission factors in Fig. 5 can be used to improve the MEGAN isoprene emission estimates as computed from Eq. (1). Figure 6 compares the resulting isoprene concentrations simulated by GEOS-Chem with a latitudinal profile of isoprene concentration measurements below $1 \mathrm{~km}$ across western Africa during the African Monsoon Multidisciplinary Analysis (AMMA) wet season aircraft campaign in July-August 2006 (Murphy et al., 2010). There is a strong vegetation gradient along the AMMA flight track from the Gulf of Guinea to Benin woodlands to arid conditions in the north that is reflected in the isoprene data. Simulated
Table 2. Isoprene emission factors for African plant functional types ${ }^{\mathrm{a}}$.

\begin{tabular}{lcc}
\hline \multirow{2}{*}{ Plant functional type } & \multicolumn{2}{c}{$\begin{array}{c}\text { Emission factor } \\
{\left[\mathrm{mg} \mathrm{C} \mathrm{m}^{-2} \mathrm{~h}^{-1}\right]}\end{array}$} \\
\cline { 2 - 3 } & MEGAN & OMI \\
\hline MODIS IGBP classification ${ }^{\mathrm{b}}$ & & \\
\hline Evergreen broadleaf trees & $4.3 \pm 2.0$ & $2.7 \pm 1.0$ \\
Deciduous broadleaf trees & $4.4 \pm 1.7$ & $2.9 \pm 0.2$ \\
Woody savannas & $3.2 \pm 1.3$ & $2.6 \pm 1.0$ \\
Savannas & $2.9 \pm 1.2$ & $2.3 \pm 0.8$ \\
Shrubs & $3.0 \pm 1.3$ & $1.6 \pm 0.8$ \\
Grasses & $1.8 \pm 0.9$ & $1.6 \pm 0.9$ \\
Crops & $1.4 \pm 0.9$ & $1.6 \pm 0.6$ \\
Mosaic of crops and natural vegetation & $2.3 \pm 1.1$ & $2.5 \pm 1.0$ \\
\hline GLC 2000 classification & & \\
\hline Evergreen broadleaf trees & & \\
Deciduous broadleaf trees & $4.4 \pm 1.9$ & $2.5 \pm 1.0$ \\
Shrubs & $3.0 \pm 1.3$ & $2.7 \pm 0.9$ \\
Herbs & $3.1 \pm 1.6$ & $2.2 \pm 1.0$ \\
Sparse herbs or shrubs & $2.4 \pm 1.3$ & $1.9 \pm 0.9$ \\
Cultivated land & $2.4 \pm 1.2$ & $1.5 \pm 0.7$ \\
Mosaic of crops and natural vegetation & $1.8 \pm 1.1$ & $2.2 \pm 0.9$ \\
Mosaic of crops and shrubs or grasses & $2.6 \pm 1.3$ & $2.7 \pm 0.7$ \\
\hline
\end{tabular}

${ }^{\text {a }}$ Isoprene emission factor $E_{O}$ in Eq. (1) at standard conditions of air temperature $(303 \mathrm{~K})$ and photosynthetically active radiation $\left(1000 \mu \mathrm{mol}\right.$ photons $\left.\mathrm{m}^{-2} \mathrm{~s}^{-1}\right)$. Values are means and standard deviations obtained by mapping the $E_{o}$ data from Fig. 5 onto the MODIS IGBP and GLC 2000 land maps. Plant functional type classifications are as given by each land map. ${ }^{b}$ Friedl et al. (2002) and shown in Fig. 1. ${ }^{\mathrm{c}}$ Mayaux et al. (2006).

isoprene in GEOS-Chem is a factor of 2 too low over Benin woodlands, likely due to a seasonal low bias in MODIS LAI over western Africa from cloud contamination (Gessner et al., 2013). Isoprene emissions over the AMMA domain are sensitive not only to LAI but also MEGAN emission factors (Ferreira et al., 2010). The OMI-derived emission factors are much better able to reproduce the latitudinal gradient than the original MEGAN emission factors, including in particular the decline to the north associated with increased aridity. Throughout Africa MEGAN emission factors are too high for semi-arid PFTs, as indicated by the overestimate in MEGAN for GLC 2000 sparse herb/shrub cover in Table 2.

\section{Implications for oxidants and aerosols}

We use the GEOS-Chem chemical transport model to (1) evaluate the change in atmospheric composition that results from replacing MEGAN emission factors with those obtained using OMI, and (2) determine the impact of isoprene emissions on aerosols and oxidants. GEOS-Chem includes the standard representation of oxidant-aerosol chemistry as described for example by Mao et al. (2010) with updates to the isoprene oxidation (Paulot et al., 2009a, b). 

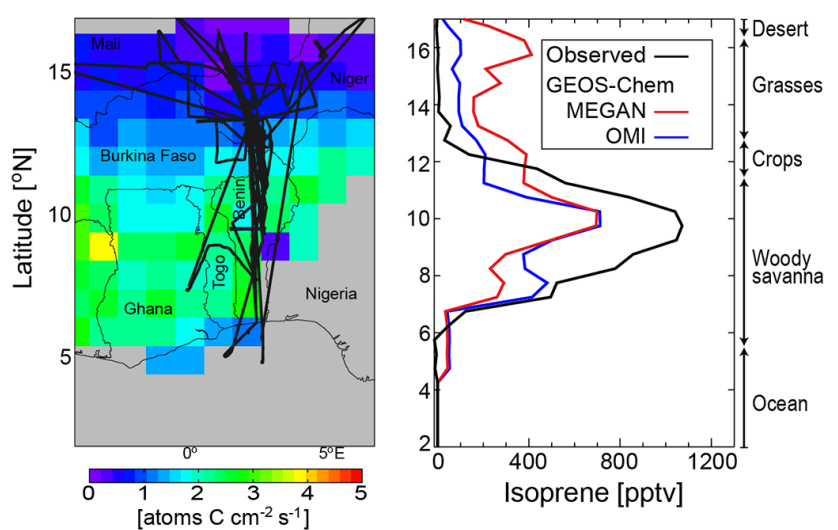

Figure 6. Latitudinal variability of isoprene in western Africa. Left panel shows the July-August 2006 AMMA flight tracks superimposed on July-August 2005-2009 OMI-derived isoprene emissions (Marais et al., 2012). Right panel shows boundary-layer $(<1 \mathrm{~km})$ isoprene concentrations along the AMMA flight tracks; observations averaged over $0.5^{\circ}$ latitude bands are compared to GEOSChem model results using either MEGAN or OMI-derived isoprene emission factors $E_{o}$. Dominant MODIS IGBP biomes along the flight tracks are indicated.

Total annual isoprene emissions in Africa averaged over 2005-2009 using OMI-derived emission factors are $77 \mathrm{Tg} \mathrm{Ca}^{-1}$, as compared to $104 \mathrm{Tg} \mathrm{Ca}^{-1}$ in MEGANv2.1. The difference is mainly for the equatorial evergreen forest PFT in central Africa, where OMI-derived isoprene emissions are 2-3 times lower than MEGAN. GEOS-Chem using OMI-derived isoprene emissions indicates a factor of 4 increase in boundary layer $\mathrm{OH}$ concentrations over central Africa relative to MEGAN, a 4 ppbv increase in surface $\mathrm{O}_{3}$, and an $8 \mathrm{ppbv}$ decrease in surface isoprene.

Figure 7 shows the effect of African isoprene emissions (using OMI-derived emission factors) on surface concentrations of daily maximum $8 \mathrm{~h}$ average (MDA8) $\mathrm{O}_{3}$, particulate matter $(\mathrm{PM}), \mathrm{NO}_{\mathrm{x}}$, and $\mathrm{OH}$. The largest effect on $\mathrm{O}_{3}$ is over western Africa because of high anthropogenic, soil, and biomass burning $\mathrm{NO}_{\mathrm{x}}$ emissions (Marais et al., 2014). The largest effect on PM is also over western Africa and reflects the availability of high preexisting primary PM from combustion (biomass burning and fuel) on which isoprene oxidation products can condense. $\mathrm{NO}_{\mathrm{x}}$ declines in western Africa and the tropics due to formation of isoprene nitrates. Loss of $\mathrm{OH}$ from reaction with isoprene is highest in the tropics where low levels of $\mathrm{NO}_{\mathrm{x}}$ limit the recycling of $\mathrm{HO}_{\mathrm{x}}$ radicals.

\section{Conclusions}

We used a 2005-2009 data set of monthly isoprene emissions in Africa derived from OMI satellite observations of HCHO to study the factors controlling these emissions in different areas of the continent. Our goal was to achieve a better representation of isoprene emission in CTMs, in part through
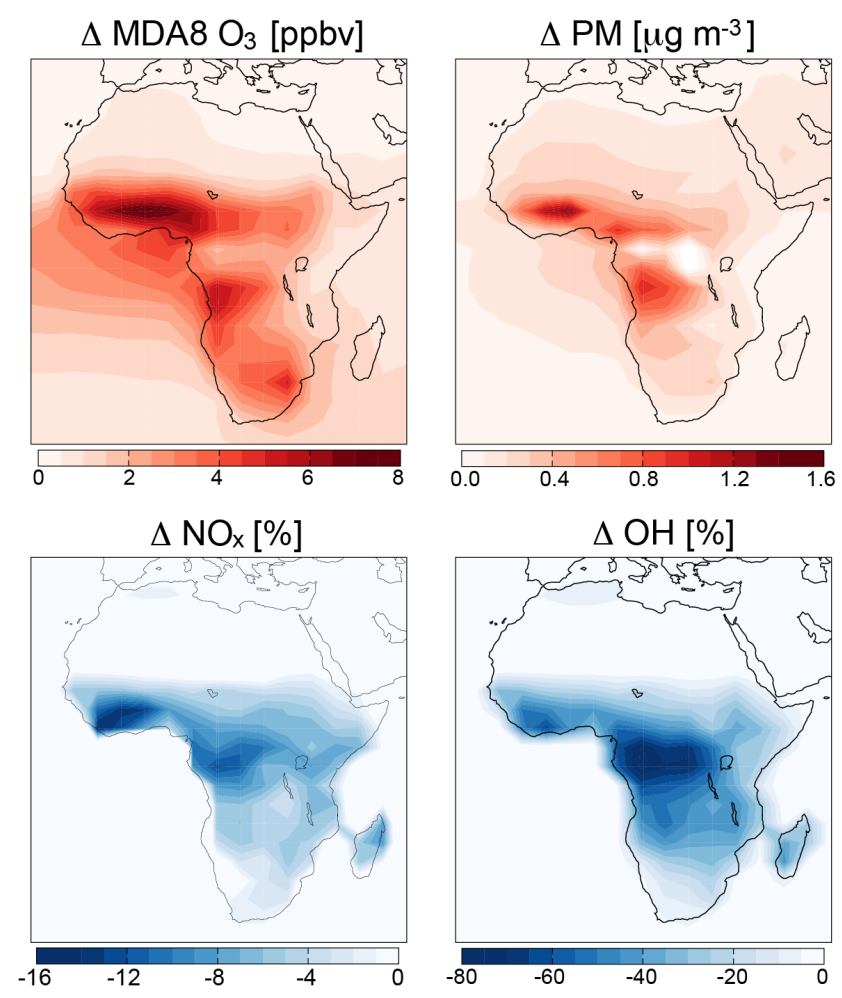

Figure 7. Effect of African isoprene emissions on regional oxidant and particulate matter (PM) concentrations in surface air. Shown are the annual mean differences $\Delta$ between GEOS-Chem simulations with and without African isoprene emissions. Isoprene emission is computed using OMI-derived emission factors.

evaluation and improvement of the commonly used MEGAN emission inventory, and to examine the implications for oxidants and aerosols over the continent.

We began by evaluating the OMI-derived isoprene emissions with REA flux measurements obtained from abovecanopy towers and aircraft during African field campaigns. OMI-derived isoprene emissions are on average 2 times higher than REA measurements over the equatorial forest and woody savannas, but this could reflect biases in the measurements. MEGAN emissions are 5-10 times higher.

We subdivided Africa into three seasonally and ecologically coherent regions to examine the seasonality in OMIderived isoprene emissions, and compare to the seasonality in MEGAN and in driving environmental variables. Equatorial forests exhibit weak seasonality that is driven predominantly by temperature, while seasonality in savannas is driven by both temperature and LAI, in a manner consistent with MEGAN.

Isoprene emissions in MEGAN are computed as the product of (1) an emission factor $E_{o}$ characteristic of the PFT, (2) the LAI, and (3) activity factors dependent on local environmental variables. We applied the LAI and MEGAN activity factors to our OMI-derived isoprene emissions to obtain emission factors representative of different PFTs. These 
agree well with the ensemble of leaf-level flux measurements in Africa and imply large downward corrections to MEGAN emission factors for equatorial forests and semi-arid vegetation. Such corrections are consistent with the latitudinal gradient of isoprene across western Africa measured in the AMMA field campaign.

The OMI-derived emission factors can be incorporated into the MEGAN formalism (Eq. 1) to improve modeling of isoprene emissions in Africa. The resulting isoprene emissions for the continent are $77 \mathrm{Tg} \mathrm{Ca}^{-1}$, as compared to $104 \mathrm{Tg} \mathrm{Ca}^{-1}$ in the standard MEGAN inventory. Most of the difference is over equatorial Africa. We conducted GEOSChem simulations with and without African isoprene emissions (using OMI-derived emission factors) to examine the impact on regional PM and oxidants. The largest effect of isoprene emissions on surface $\mathrm{O}_{3}$ is over western Africa where $\mathrm{NO}_{\mathrm{x}}$ is high, and the largest effect on PM is also over western Africa because of preexisting high concentrations of primary PM from combustion.

Acknowledgements. This work was funded by NASA through the Aura Science Team and by a South African National Research Scholarship for Study Abroad awarded to E. A. Marais. The United States Environmental Protection Agency through its Office of Research and Development collaborated in the research described here. It has been subjected to Agency review and approved for publication, but may not necessarily reflect official Agency policy.

Edited by: Q. Errera

\section{References}

Barkley, M. P., Palmer, P. I., Kuhn, U., Kesselmeier, J., Chance, K., Kurosu, T. P., Martin, R. V., Helmig, D., and Guenther, A.: Net ecosystem fluxes of isoprene over tropical South America inferred from Global Ozone Monitoring Experiment (GOME) observations of HCHO columns, J. Geophys. Res., 113, D20304, doi:10.1029/2008JD009863, 2008.

Barkley, M. P., Palmer, P. I., De Smedt, I., Karl, T., Guenther, A., and Van Roozendael, M.: Regulated large-scale annual shutdown of Amazonian isoprene emissions?, Geophys. Res. Lett., 36, L04803, doi:10.1029/2008GL036843, 2009.

Casadio, S., Arino, O., and Serpe, D.: Gas flaring monitoring from space using the ATSR instrument series, Remote Sens. Environ., 116, 239-249, doi:10.1016/j.rse.2010.11.022, 2012.

Claeys, M., Graham, B., Vas, G., Wang, W., Vermeylen, R., Pashynska, V., Cafmeyer, J., Guyon, P., Andreae, M. O., Artaxo, P., and Maenhaut, W.: Formation of secondary organic aerosols through photooxidation of isoprene, Science, 303, 1173-1176, doi:10.1126/science.1092805, 2004.

Curci, G., Palmer, P. I., Kurosu, T. P., Chance, K., and Visconti, G.: Estimating European volatile organic compound emissions using satellite observations of formaldehyde from the Ozone Monitoring Instrument, Atmos. Chem. Phys., 10, 11501-11517, doi:10.5194/acp-10-11501-2010, 2010.
Dufour, G., Wittrock, F., Camredon, M., Beekmann, M., Richter, A., Aumont, B., and Burrows, J. P.: SCIAMACHY formaldehyde observations: constraint for isoprene emission estimates over Europe?, Atmos. Chem. Phys., 9, 1647-1664, doi:10.5194/acp-91647-2009, 2009.

Ferreira, J., Reeves, C. E., Murphy, J. G., Garcia-Carreras, L., Parker, D. J., and Oram, D. E.: Isoprene emissions modelling for West Africa: MEGAN model evaluation and sensitivity analysis, Atmos. Chem. Phys., 10, 8453-8467, doi:10.5194/acp-10-84532010, 2010.

Friedl, M. A., McIver, D. K., Hodges, J. C. F., Zhang, X. Y., Muchoney, D., Strahler, A. H., Woodcock, C. E., Gopal, S., Schneider, A., Cooper, A., Baccini, A., Gao, F., and Schaaf, C.: Global land cover mapping from MODIS: algorithms and early results, Remote Sens. Environ., 83, 287-302, 2002.

Fu, T.-M., Jacob, D. J., Palmer, P. I., Chance, K., Wang, Y. X., Barletta, B., Blake, D. R., Stanton, J. C., and Pilling, M. J.: Space-based formaldehyde measurements as constraints on volatile organic compound emissions in east and south Asia and implications for ozone, J. Geophys. Res., 112, D06312, doi:10.1029/2006JD007853, 2007.

Gessner, U., Niklaus, M., Kuenzer, C., and Dech, S.: Intercomparison of leaf area index products for a gradient of sub-humid to arid environments in West Africa, Remote Sens., 5, 1235-1257, doi:10.3390/rs5031235, 2013.

Greenberg, J. P., Guenther, A. B., Madronich, S., Baugh, W., Ginoux, P., Druilhet, A., Delmas, R., and Delon, C.: Biogenic volatile organic compound emissions in central Africa during the Experiment for the Regional Sources and Sinks of Oxidants (EXPRESSO) biomass burning season, J. Geophys. Res., 104, D23, 30659-30671, doi:10.1029/1999JD900475, 1999.

Guenther, A., Hewitt, C. N., Erickson, D., Fall, R., Geron, C., Graedel, T., Harley, P., Klinger, L., Lerdau, M., McKay, W. A., Pierce, T., Scholes, B., Steinbrecher, R., Tallamraju, R., Taylor, J., and Zimmerman, P.: A global model of natural volatile organic compound emissions, J. Geophys. Res., 100, D5, 88738892, doi:10.1029/94JD02950, 1995.

Guenther, A., Otter, L., Zimmerman, P., Greenberg, J., Scholes, R., and Scholes, M.: Biogenic hydrocarbon emissions from southern African savannas, J. Geophys. Res., 101, D20, 25859-25865, doi:10.1029/96JD02597, 1996.

Guenther, A., Baugh, B., Brasseur, G., Greenberg, J., Harley, P., Klinger, L., Serça, D., and Vierling, L.: Isoprene emission estimates and uncertainties for the Central African EXPRESSO study domain, J. Geophys. Res., 104, 30625-30639, doi:10.1029/1999JD900391, 1999.

Guenther, A., Karl, T., Harley, P., Wiedinmyer, C., Palmer, P. I., and Geron, C.: Estimates of global terrestrial isoprene emissions using MEGAN (Model of Emissions of Gases and Aerosols from Nature), Atmos. Chem. Phys., 6, 3181-3210, doi:10.5194/acp-63181-2006, 2006.

Guenther, A. B., Jiang, X., Heald, C. L., Sakulyanontvittaya, T., Duhl, T., Emmons, L. K., and Wang, X.: The Model of Emissions of Gases and Aerosols from Nature version 2.1 (MEGAN2.1): an extended and updated framework for modeling biogenic emissions, Geosci. Model Dev., 5, 1471-1492, doi:10.5194/gmd-51471-2012, 2012.

Harley, P., Otter, L., Guenther, A., and Greenberg, J.: Micrometeorological and leaf-level measurements of isoprene emissions 
from a southern African savanna, J. Geophys. Res., 108, 8468, doi:10.1029/2002JD002592, 2003.

Janicot, S., Thorncroft, C. D., Ali, A., Asencio, N., Berry, G., Bock, O., Bourles, B., Caniaux, G., Chauvin, F., Deme, A., Kergoat, L., Lafore, J.-P., Lavaysse, C., Lebel, T., Marticorena, B., Mounier, F., Nedelec, P., Redelsperger, J.-L., Ravegnani, F., Reeves, C. E., Roca, R., de Rosnay, P., Schlager, H., Sultan, B., Tomasini, M., Ulanovsky, A., and ACMAD forecasters team: Large-scale overview of the summer monsoon over West Africa during the AMMA field experiment in 2006, Ann. Geophys., 26, 25692595, doi:10.5194/angeo-26-2569-2008, 2008.

Karl, T., Misztal, P. K., Jonsson, H. H., Shertz, S., Goldstein, A. H., and Guenther, A. B.: Airborne flux measurements of BVOCs above Californian oak forests: Experimental investigation of surface and entrainment fluxes, $\mathrm{OH}$ densities and Dahmköhler numbers, J. Atmos. Sci., 70, 3277-3287, doi:10.1175/JAS-D-13054.1, 2013.

Klinger, L. F., Greenberg, J., Guenther, A., Tyndall, G., Zimmerman, P., M'Bangui, M., Moutsamboté, J.-M., and Kenfack, D.: Patterns in volatile organic compound emissions along a savanna-rainforest gradient in central Africa, J. Geophys. Res., 103, 1443-1454, doi:10.1029/97JD02928, 1998.

Lelieveld, J., Butler, T. M., Crowley, J. N., Dillon, T. J., Fischer, H., Ganzeveld, L., Harder, H., Lawrence, M. G., Martinez, M., Taraborrelli, D., and Williams, J.: Atmospheric oxidation capacity sustained by a tropical forest, Nature, 452, 737-740, doi:10.1038/nature06870, 2008.

Levelt, P. F., van den Oord, G. H. J., Dobber, M. R., Mälkki, A., Visser, H., de Vries, J., Stammes, P., Lundell, J. O. V., and Saari, H.: The Ozone Monitoring Instrument, IEEE T. Geosci. Remote Sens., 44, 1093-1101, doi:10.1109/TGRS.2006.872333, 2006.

Mao, J., Jacob, D. J., Evans, M. J., Olson, J. R., Ren, X., Brune, W. H., St. Clair, J. M., Crounse, J. D., Spencer, K. M., Beaver, M. R., Wennberg, P. O., Cubison, M. J., Jimenez, J. L., Fried, A., Weibring, P., Walega, J. G., Hall, S. R., Weinheimer, A. J., Cohen, R. C., Chen, G., Crawford, J. H., McNaughton, C., Clarke, A. D., Jaeglé, L., Fisher, J. A., Yantosca, R. M., Le Sager, P., and Carouge, $\mathrm{C}$. . Chemistry of hydrogen oxide radicals $\left(\mathrm{HO}_{\mathrm{x}}\right)$ in the Arctic troposphere in spring, Atmos. Chem. Phys., 10, 58235838, doi:10.5194/acp-10-5823-2010, 2010.

Marais, E. A., Jacob, D. J., Kurosu, T. P., Chance, K., Murphy, J. G., Reeves, C., Mills, G., Casadio, S., Millet, D. B., Barkley, M. P., Paulot, F., and Mao, J.: Isoprene emissions in Africa inferred from OMI observations of formaldehyde columns, Atmos. Chem. Phys., 12, 6219-6235, doi:10.5194/acp-12-62192012, 2012.

Marais, E. A., Jacob, D. J., Wecht, K., Lerot, C., Zhang, L., Yu, K., Kurosu, T. P., Chance, K., and Sauvage, B.: Anthropogenic emissions in Nigeria and implications for ozone air quality: a view from space, Atmos. Environ., submitted, 2014.

Mayaux, P., Eva, H., Gallego, J., Strahler, A. H., Herold, M., Agrawal, S., Naumov, S., De Miranda, E. E., Di Bella, C. M., Ordoyne, C., Kopin, Y., and Roy, P. S.: Validation of the Global Land Cover 2000 map, IEEE T. Geosci. Remote Sens., 44, 1728 1739, doi:10.1109/TGRS.2006.864370, 2006.

Millet, D. B., Jacob, D. J., Boersma, K. F., Fu, T.-M., Kurosu, T. P., Chance, K., Heald, C. L., and Guenther, A.: Spatial distribution of isoprene emissions from North America derived from formaldehyde column measurements by the OMI satellite sen- sor, J. Geophys. Res., 113, D02307, doi:10.1029/2007JD008950, 2008.

Murphy, J. G., Oram, D. E., and Reeves, C. E.: Measurements of volatile organic compounds over West Africa, Atmos. Chem. Phys., 10, 5281-5294, doi:10.5194/acp-10-5281-2010, 2010.

Olivier, J. G. J., Bouwman, A. F., van der Maas, C. W. M., Berdowski, J. J. M., Veldt, C., Bloos, J. P. J., Visschedijk, A. J. H., Zandveld, P. Y. J., and Haverlag, J. L.: Description of EDGAR Version 2.0: A set of global emission inventories of greenhouse gases and ozone-depleting substances for all anthropogenic and most natural sources on a per country basis and on $1 \times 1^{\circ}$ grid, Bilthoven, The Netherlands, 1996 .

Olson, D. M., Dinerstein, E., Wikramanayake, E. D., Burgess, N. D., Powell, G. V. N., Underwood, E. C., D’ Amico, J. A., Itoua, I., Strand, H. E., Morrison, J. C., Loucks, C. J., Allnutt, T. F., Rickets, T. H., Kura, Y., Lamoreux, J. F., Wettengel, W. W., Hedao, P., and Kassem, K. R.: Terrestrial ecoregions of the world: a new map of life on earth, BioScience, 51, 933-938, 2001.

Otter, L. B., Guenther, A., and Greenberg, J.: Seasonal and spatial variations in biogenic hydrocarbon emissions from southern African savannas and woodlands, Atmos. Environ., 36, 42654275, 2002.

Otter, L., Guenther, A., Wiedinmyer, C., Fleming, G., Harley, P., and Greenberg, J.: Spatial and temporal variations in biogenic volatile organic compound emissions for Africa south of the equator, J. Geophys. Res., 108, 8505, doi:10.1029/2002JD002609, 2003.

Palmer, P. I., Jacob, D. J., Chance, K., Martin, R. V., Spurr, R. J. D., Kurosu, T. P., Bey, I., Yantosca, R., Fiore, A., and Li, Q.: Air mass factor formulation for spectroscopic measurements from satellites: Application to formaldehyde retrievals from the Global Ozone Monitoring Experiment, J. Geophys. Res., 106, 1453914550, doi:10.1029/2000JD900772, 2001.

Palmer, P. I., Jacob, D. J., Fiore, A. M., Martin, R. V., Chance, K., and Kurosu, T. P.: Mapping isoprene emissions over North America using formaldehyde column observations from space, J. Geophys. Res., 108, 4180, doi:10.1029/2002JD002153, 2003.

Palmer, P. I., Abbot, D. S., Fu, T.-M., Jacob, D. J., Chance, K., Kurosu, T. P., Guenther, A., Wiedinmyer, C., Stanton, J. C., Pilling, M. J., Pressley, S. N., Lamb, B., and Sumner, A. L.: Quantifying the seasonal and interannual variability of North American isoprene emissions using satellite observations of the formaldehyde column, J. Geophys. Res., 111, D12315, doi:10.1029/2005JD006689, 2006.

Paulot, F., Crounse, J. D., Kjaergaard, H. G., Kroll, J. H., Seinfeld, J. H., and Wennberg, P. O.: Isoprene photooxidation: new insights into the production of acids and organic nitrates, Atmos. Chem. Phys., 9, 1479-1501, doi:10.5194/acp-9-1479-2009, 2009a.

Paulot, F., Crounse, J. D., Kjaergaard, H. G., Kürten, A., St Clair, J. M., Seinfeld, J. H., and Wennberg, P. O.: Unexpected epoxide formation in the gas-phase photooxidation of isoprene, Science, 325, 730-733, doi:10.1126/science.1172910, 2009 b.

Paulot, F., Henze, D. K., and Wennberg, P. O.: Impact of the isoprene photochemical cascade on tropical ozone, Atmos. Chem. Phys., 12, 1307-1325, doi:10.5194/acp-12-1307-2012, 2012.

Pfister, G. G., Emmons, L. K., Hess, P. G., Lamarque, J.-F., Orlando, J. J., Walters, S., Guenther, A., Palmer, P. I., and Lawrence, P. J.: Contribution of isoprene to chemical budgets: A model tracer 
study with the NCAR CTM MOZART-4, J. Geophys. Res., 113, D05308, doi:10.1029/2007JD008948, 2008.

Ren, X., Olson, J. R., Crawford, J. H., Brune, W. H., Mao, J., Long, R. B., Chen, Z., Chen, G., Avery, M. A., Sachse, G. W., Barrick, J. D., Diskin, G. S., Huey, L. G., Fried, A., Cohen, R. C., Heikes, B., Wennberg, P. O., Singh, H. B., Blake, D. R., and Shetter, R. E.: $\mathrm{HO}_{\mathrm{x}}$ chemistry during INTEX-A 2004: Observation, model calculation, and comparison with previous studies, J. Geophys. Res., 113, D05310, doi:10.1029/2007JD009166, 2008.

Serça, D., Guenther, A., Klinger, L., Vierling, L., Harley, P., Druilhet, A., Greenberg, J., Baker, B., Baugh, W., Bouka-Biona, C., and Loemba-Ndembi, J.: EXPRESSO flux measurements at upland and lowland Congo tropical forest site, Tellus B, 53, 220 234, 2001

Sharkey, T. D., and Yeh, S.: Isoprene emission from plants, Annu. Rev. Plant Physiol. Plant Mol. Biol., 52, 407-436, 2001.

Shim, C., Wang, Y., Choi, Y., Palmer, P. I., Abbot, D. S., and Chance, K.: Constraining global isoprene emissions with Global Ozone Monitoring Experiment (GOME) formaldehyde column measurements, J. Geophys. Res., 110, D24301, doi:10.1029/2004JD005629, 2005.

Spurr, R. J. D., Kurosu, T. P., and Chance, K. V.: A linearized discrete ordinate radiative transfer model for atmospheric remotesensing retrieval, J. Quant. Spectrosc. Ra., 68, 689-735, 2001.

Stavrakou, T., Müller, J.-F., De Smedt, I., Van Roozendael, M., van der Werf, G. R., Giglio, L., and Guenther, A.: Evaluating the performance of pyrogenic and biogenic emission inventories against one decade of space-based formaldehyde columns, Atmos. Chem. Phys., 9, 1037-1060, doi:10.5194/acp-9-1037-2009, 2009a.
Stavrakou, T., Müller, J.-F., De Smedt, I., Van Roozendael, M., van der Werf, G. R., Giglio, L., and Guenther, A.: Global emissions of non-methane hydrocarbons deduced from SCIAMACHY formaldehyde columns through 2003-2006, Atmos. Chem. Phys., 9, 3663-3679, doi:10.5194/acp-9-3663-2009, 2009b.

Torres, O., Tanskanen, A., Veihelmann, B., Ahn, C., Braak, R., Bhartia, P. K., Veefkind, P., and Levelt, P.: Aerosols and surface UV products from Ozone Monitoring Instrument observations: An overview, J. Geophys. Res., 112, D24S47, doi:10.1029/2007JD008809, 2007.

Trainer, M., Williams, E. J., Parrish, D. D., Buhr, M. P., Allwine, E. J., Westberg, H. H., Fehsenfeld, F. C., and Liu, S. C.: Models and observations of the impact of natural hydrocarbons on rural ozone, Nature, 329, 705-707, 1987.

White, F.: The Vegetation of Africa - a descriptive memoir to accompany the UNESCO/AETFAT/UNSO vegetation map of Africa; Natural Resources Research Report XX, U. N. Educational, Scientific and Cultural Organization, 356 pp., Paris, 1983.

Yang, W., Shabanov, N. V., Huang, D., Wang, W., Dickinson, R. E., Nemani, R. R., Knyazikhin, Y., and Myneni, R. B.: Analysis of leaf area index products from combination of MODIS Terra and Aqua data, Remote Sens. Environ., 104, 297-312, doi:10.1016/j.rse.2006.04.016, 2006. 